\title{
A Study on Behaviors of the Government toward "Return Grazing Land to Grass- land" Policy
}

\author{
Guo Yanyu ${ }^{1}$ Zou Shixiang $^{2}$ \\ ${ }^{1}$ China University of geosciences (Beijing) \\ ${ }^{2}$ China University of geosciences (Beijing)
}

\begin{abstract}
In order to protect the ecological environment of grasslands and to improve people's livelihood, Chinese government proposed a policy called "Return Grazing Land to Grassland". This is a great strategy on ecological construction of grasslands. The government has played a very important role since the policy was carried out in 2003. It is significant about studying and analyzing the behaviors of the government toward the policy, summarizing the positive and negative aspects which promote or hinder the policy, and putting forward some advices and suggestions.
\end{abstract}

Keywords: "Return Grazing Land to Grassland" Policy; Behaviors of the Government ; Study

China has very rich grassland resources, but steppe ecology has been damaged critically as well as grassland degradation and desertification had become more and more serious in recent years. The deterioration of the grassland ecological environment, not only affects the livelihood of farmers and herdsmen, but also restricts the development of animal husbandry, and even poses a great threat to the country's ecological security. In the face of such a situation, in 2003 the country launched a major policy -- "Re- turn Grazing Land to Grassland". It is one of the major projects to improve the ecological environment in the western part of China and also an important task to implement the strategy of sustainable development.

The problem of returning grazing land to grassland has been paid much attention because of the more and more serious desertification in recent years. Moreover in China the core of solving the desertification problem is the policy implementation of government. To study on the behaviors of the government toward "Return Grazing Land to Grassland" policy, to search the effective measures to prevent the desertification of land, to realize the sustainable development of the environment, which have great theoretical value and practical significance.

\section{The connotation of the govern- ment's behaviors toward "Return Grazing Land to Grassland" policy}

The so-called government behavior is in a certain period of time in order to realize the interests of the country and the development of social, the government takes a series of activities and specific actions. These activities and actions include guiding behaviors, organizational behaviors, coordination behaviors, service behaviors and control behaviors. In addition, its realization methods mainly include administrative means, economic 
means, legal means and means of ideological education.

The behaviors of the government are the basic part of the governmental function system, and the whole process and activities are the concrete embodiment of the government function. The behaviors of the government toward "Return Grazing Land to Grassland" policy are the specific behaviors of government's departments during guiding and regulating the policy, which include administrative decision, administrative leadership, administrative enforcement and administrative supervision. At present, the state, the community and the herdsmen are beneficiary of grassland resources. According to the principle of "who benefits, who protects", the state, the community and the farmers have responsibilities to protect grassland resources. Grassland resource is a special kind of public resources, because the property right of the pasture resources is not clear, in addition to the part owned by the collective, the rest are owned by the state. As a result the government becomes the core of management of grassland resources, and the public awareness of protecting grassland has not yet reached its height, so the government naturally becomes the main body of policy implementation, and bears the main responsibilities.

2. The reflection of the behaviors of the government toward "Return Grazing Land to Grassland" policy.

\subsection{Leading the work of returning grazing land to grassland, making the overall plan to the policy and introducing the relevant regula- tions}

"Return Grazing Land to Grassland" policy is a major decision which is made from the perspective of sustainable development. The government has estab- lished basic protection systems to protect grassland with the measure of taking the fence, improving planting, grazing prohibition, resting grazing, blocking rotational grazing and giving the nomads certain economic compensation. Because of that, the almost degraded grassland has been effectively restored, natural pasture has rehabilitated. The government also had built up the ecological system which is adapted to sustainable development of grassland animal husbandry, shifted herdsmen's production and living ways, adjusted the structure of herds, and helped the herdsmen improve their income.

In order to ensure the policy is implemented smoothly, the government has issued a series of policies. For example " Grassland Law of the People's Republic of China" "Grassland fire prevention regulations of the People's Republic of China" "Regulations on the nature protection regions of the People's Republic of China" "The management measures of the ecological environment construction projects in Inner Mongolia Autonomous Region" (try on) "the management method of return grazing land to grassland in the Inner Mongolia autonomous region"(try on) "the Inner Mongolia $\mathrm{Au}$ tonomous Region stage of grazing, rotational grazing compensation management measures" "the approval scheme of Grazing Withdrawal Project in Inner Mongolia Autonomous Region" and related documents. These principles and policies provide policy guarantee and technical support for the "Return Grazing Land to Grassland" policy.

\subsection{Supervise the Specific Implementa- tion of "Return Grazing Land to Grassland” Policy}

In order to ensure the "Return Grazing Land to Grassland" policy is carried out smoothly, the government has im- 
plemented that the relevant project teams are responsible for organizing and coordinating the work, and also has implemented the system of "who management who is responsible for". The specific units and responsible person signed liability form and sign the agreement with the herdsman, implement the various tasks in the contract form .For the important engineer project, the government chooses the contractor who has substantial and hires a special department to supervise the implementation of the whole project to ensure the quality of the construction project.

Supervise and inspect the implementation of "Return Grazing Land to Grassland" policy. The government should supervise whether accord to the provisions of the national policy, whether appear the phenomenon of going against to the provision. The content of supervision also includes the situation subsidiary which is given by the government, and whether haste phenomenon of money is held back or embezzled etc.

\subsection{Give the "Return Grazing Land to Grassland" Policy financial and technical supports and training the relate staff}

The development plan of national economy and society includes grassland protecting. To expanding the financing channels of investment, enthusiasm of all vertical organization sectors, guild the capital of unit, community and individual, and using foreign capital, the government puts these aspects in protecting and constructing the grassland resources. The state sets up a special fund for the "Return Grazing Land to Grassland" policy to give supports to herdsmen. The subsidies that the government gives to herdsmen cannot only provide support to herdsmen's live but also can provide funds for the development of production.
The government also increases investment in power, irrigation, transportation and other infrastructures, and gives appropriate subsidies to the higher cost of investment, such as grassland fence, housing, and feed processing machinery and so on. Although the subsidies provided by government are not many, they can give the herdsmen a psychological comfort. It has significance meaning for the policy.

The government also gives the implementation of the policy a great technical support. The government relies on scientific and technological progress to improve the quality of policy. Training the relate staff about policy to improve their ideological consciousness and the level of science and technology. Using modern $3 \mathrm{~S}$ Technology (QS, GPS and GIS) to detect grassland area, the productivity of grassland, the situation of degradation, the natural disasters and the efficiency of grassland ecological construction. The introduction of new technology and variety give support for artificial grass planting, feed processing development and scientific breeding technology, so that can make the majority of farmers to adapt as soon as possible.

3. The problem of the behaviors of government toward "Return Grazing Land to Grassland"

\subsection{Property right relation of grass- land resources is not clear which leads the phenomenon of "pass the buck"}

In 1985, the "Grassland Law" started be implemented, in which defined the ownership of the grassland in the form of law and set the right to use and the right to the contracted management. Provided that grassland resources accept the part under the collective ownership, the rest are owned by the state. Although grass- 
land resources belong to the state on law, the state as the owner, the position is still very fuzzy. For example the specific use right, the income right of disposal and the right of transferring has not made the relevant provisions clearly. In 1996, the land contract responsibility system started, most of the grassland is still owned by community, and only a small part of the land is contracted by herdsmen. Because the mainly body of the ownership of grassland resources is not clear, it appears the phenomenon of "pass the buck" when the government manage the of grassland resources.

In order to pursue the maximization of benefits, often blindly using of the grassland resources with the right to rentseeking behavior .Because of that the endurance of the grassland resources is ignored. Hence, there often appears the phenomenon of "have policy, there is countermeasures". Thus the central policy cannot be implemented well.

\subsection{The influence of the government performance evaluation and the "rent-seeking", blindly use and unreasonably development}

The goal of the current administrative system reform is to establish the public management which is in order to obtain the performance. At present, the higher regard the performance of work as the inspection standard for the work to a lower and any official appointments cannot do without performance. Some local governments from their own considerations, in order to the pursuit of political achievements, they only seek the growth in GDP. In order to improve the performance, the government always takes the methods to develop the local grassland resources, not only exploitate and utilize the grassland resources seriously, but also unrestrained exploitation the mineral resources around the grassland unrestrained, which leads to the destruction of grassland resources environment seriously. The damage of the ecological environment cause soil erosion and land desertification directly.

The so-called rent-seeking is also called power rent-seeking, the national public servants in order to obtain high profits and a windfall, regards the administrative power as chip to rent power to enterprise or person. Renting act is a kind of monopolistic activities; the deep reasons of rent-seeking behavior are related to the control supervision and monopoly of government. In the process of policy implementation, utilizes the uses of power, personal fame and influence of strong group to seek improper interests, activities seriously distorted rational allocation of grassland rescoures, resulting in the policy becoming complicated and corruption.

\subsection{As part of the legal system and su- pervision system, the phenomenon of the government's absence and dislocation appear}

Because of "Grassland Law" promulgated, China's grassland resources enter into the management stage, but the relevant provisions don't make clear provisions in the law, and the enforcement of law is not strong enough and has a variety of behaviors in destructing grassland. So the deterioration of the grassland environment has become more and more serious. Because of the laws are not sound and the sup erosion and law enforcement is not strong, in the process of policy implementation, some places have a very serious phenomenon of arrears of subsidies, when provides food subsidies some places sell substandard goods as best quality, give the rotten rich to herdsmen; some places converted grain into cash to charge the difference from it; in some 
places herdsmen will not get any form of subsidy etc.

Many problems exist in grassland supervision and management, such as the teams are not neat, appropriate staff is less, and relates divide of management organization is not clear. And some of the staff is not strictly in accordance with the procedures, since the administrative means are simple and crude, which makes some conflictions with herdsmen in the daily work that, influences the effect of policy implementation.

Because parts of the legal system and supervision system are not perfect, the phenomenon of government's absence and dislocation appear. Because of power rent-seeking, the government blindly uses grassland resources by their power. $\mathrm{Be}$ cause they are lured by profits, the phenomenon that the examined and approved subject is supervised by government without examined and approved subject is without anybody to care about appear, when exanimate and approve the project some governments could fight for the power. But when exercise the right of supervision; they try their best to shirk their responsibility. Power rent-seeking behaviors weaken the government's strength of the supervision and management; result in the actual operation of public policy cannot be effectively implemented.

\section{The suggestion of improve the be- haviors of the government towards the "Return Grazing to Grassland" policy}

\subsection{Clearing the property right rela- tions of the grassland resources, clarify its responsibilities}

The explicit property right relations can benefit the conduction of grassland and the accumulation of funds. At the same time, also can use the limited state investment to start the market mecha- nism .If putting the limited funds into the construction of grassland property, it can mobilize all aspects of society initiative, coordinate the interests of national, community and individual.

Clear the main body of grassland resources property right in the law. The law should clear which grassland resources belong to the state and which grassland resources are under the collective ownership. The law should also clear the income right, use right of disposal right and transfer right of grassland. Strengthening national ownership, clearing relationship among ownership, using right and administrative right, establish clear coordination mechanism between grassland owner the state and actual grassland management. A clear division of power makes them to realize their responsibilities.

\subsection{To optimize the policy subject, to transfer the functions of govern- ment, let government not simply and one-side pursuit political achievements}

Under the guidance of peopleoriented, comprehensive balanced and sustainable development concept reposition the government function, do not regard economic growth as the main part of achievement. The transformation of government functions does not mean that the local governments should give up economic construction, but the functions of the government must be changed and separate government function from enterprise management.

Implement the idea of people oriented in practical work, improving the professional ethics and Work responsibilities of the government agencies and staff, strengthening the sense of social responsibility, achieving the goal that "the power used for the people, the sentiment for the people, seeking benefit for the people". To ensure that policy can convey 
effectively, before the policy goes into effect, the government should carry out some corresponding propagandas. Moreover, the government should enforce laws strictly to prevent the illegal phenomenon, and also should accept supervision from all aspects of society. During policy implementation, the government must punish offenders, maintaining the authority and effectiveness of the policy.

\subsection{Perfect the system of legal supervi- sion to preventing the phenome- non of government absence and dislocation}

Carry out "Grassland Law" and "Regulations of grassland management in Inner Mongolia Autonomous Region" and relevant laws and regulating seriously, strengthen supervision and inspection, constantly, improve the legal system, introduce "Grazing Management Regulations" as soon as possible. To make the return grazing to grassland work can be done smoothly, the "Law must be observed and strictly enforced, and lawbreakers must be prosecuted." To prevent overgrazing based on the law. According to the rules to catch up with these behaviors.

Improve the system of supervision, strengthen the management and supervision of grassland, improve the regulatory means, strengthen the reconstruction of regulators, and train more qualified talents. The newly revised "Grassland Law of the PRC" stipulates clearly: the governments that above the level of province and autonomous region and grassland area are bigger, should establish regulator towards grassland, and be responsible for two in charge of supervising and inspecting implementation of laws and deal with violations of laws and regulations. At present, the government should straighten out the grassland management system, clear all levels of regula- tory functions and establish grassland supervision mechanism which has a clear authority, effective supervision and effective guarantee.

\section{Conclusions}

The "Return Grazing to Grassland" policy as a significant part of government projects, and its successful is directly related to ecological, economic and social sustainable development. For so many years, has made great achievements, greatly improved the ecological environment of the region, and also promotes the poverty of local herdsmen. Although there are also some problems, with the policy of development, these problems will be overcome one by one, and achieve the ultimate goal of the "Return Grazing to Grassland" policy.

\section{References}

[1] Chen Mang, Xu Bin, "The social auto nomy and the transformation of political $\mathrm{f}$ unction," [M]. China Society Press, pp.21 7-221, 2005

[2] Qin Jun, Wang Aifang, "The reasons and countermeasures of power rent-seeki ng ,'[M]. Qian Yan, 2003.6

[3] Huang Delin, Wang Jimin, "The analy sis of grazing ban policy in China pastora 1 area"']J],Chinese Agricultural Science B ulletin 2004

[4] Yang Ru-rong, "Grazing with drawl a nd management of grassland, issues over meaning and technological standards"[J]. Pratacultural Science,2004

[5] Guo Xiaolan, "Grassland Laws and R egulations and the Protection of Grasslan d Resources "[M].Yin Shan Academic Jou rnal,2012

[6] Pan Ke, Zhu Yubi, "Discussion and A nalysis of Government Behaviors in Farm land Conservation" [J], Chinese Agricultu ral Science Bulletin Vol.201 No.7 2005 